JOURNAL OF SECURITY AND SUSTAINABILITY ISSUES

ISSN 2029-7017 print/ISSN 2029-7025 online

2021 Volume 11

https://doi.org/10.47459/jssi.2021.11.21

\title{
EXISTENTIAL EXPERIENCES AND MACHIAVELLIANISM OF RECIDIVISTS - EXPLORING RELATIONSHIPS IMPORTANT FOR PENITENTIARY STUDIES
}

\author{
Jarosław Rychlik \\ Academy of Justice, 50 Wiśniowa Street, 02-520 Warsaw, Poland \\ E-mail: jaroslaw.rychlik@swws.edu.pl
}

Received 15 November 2020; accepted 29 March 2021; published 30 June 2021

\begin{abstract}
This article is an attempt to deepen the knowledge about the relationships between Machiavellianism and the search for and experience of a sense of the meaning in life in penitentiary recidivists. The study emphasises the role of this knowledge in penitentiary interactions. The significance of Machiavellianism for penitentiary studies is conditioned by the fact that this construct captures the essence of the attitudes and beliefs illustrating the relation of individuals to the social world. Moreover, the significance of the problem of searching for and experiencing the meaning in life in relation to the area of penitentiary social rehabilitation is conditioned by the issue of linking these constructs with the aspect of positive change and achieving general adaptation. The study indicates a number of theoretical and empirical premises justifying the occurrence of direct relationships between the area of Machiavellianism and the sphere of existential experiences. The research objective was formulated based these assumptions and concerned the determination of the relationship between Machiavellianism and the meaning of life in repeatedly incarcerated convicts. A group of 59 penitentiary recidivists (aged 27 to 68 ; $M=39.75, S D=8.84$ ) was tested using the Machiavellian scale (Mach $I V)$ and the Meaning in Life Questionnaire $(M L Q)$, which enabled the measurement of the search for and presence of meaning in life. The relationships between the variables were determined by correlation. The analyses showed the existence of numerous significant relationships between the Machiavellian syndrome and the search for and presence of meaning in life. A greater overall level of Machiavellianism was associated with a lower intensity of the search for and the presence of meaning in life. The obtained results have implications for penitentiary practice with regards to influencing convicted recidivists. In light of the acquired results, it is justified to include educational and psycho-corrective elements that undermine Machiavellian beliefs, which is a factor supporting the orientation towards the search for meaning in life and has potential to create meaning.
\end{abstract}

Keywords: Machiavellianism; searching for meaning in life; presence of meaning in life; social security; rehabilitation

Reference to this paper should be made as follows: Rychlik, J. 2021. Existential experiences and machiavellianism of recidivists - exploring relationships important for penitentiary studies. Journal of Security and Sustainability Issues, 11, $245-254$.

https://doi.org/10.47459/jssi.2021.11.21

JEL Classifications: Z00

Additional disciplines: penitentiary, social rehabilitation

\section{Introduction}

This article raises the issue of the relationship between existential experiences in the form of the presence of and search for meaning in life and the Machiavellian syndrome in penitentiary recidivists. It is difficult to underestimate the penitentiary importance of establishing a relationship between the presence of and search for meaning in life and Machiavellianism in convicted recidivists. The significance of conducting research in this area results from the key legal provisions regulating the functioning of the Polish penitentiary system. It is worth mentioning the provisions of Article $67 \S 1$ of the Executive Penal Code, which indicate that the rehabilitation purpose of the execution of the penalty of prison sentence is "to induce in the convict the will to cooperate in shaping their socially desirable attitudes, in particular a sense of responsibility as well as the need to respect the legal order and thus refrain from returning to crime". Referring to the issues raised, it is also worth mentioning the obligation 
resulting from Article $97 \S 1$ of the same code, which defines specific goals of therapy conducted in conditions of penitentiary isolation focused on preventing the deepening of pathological personality traits, restoring mental balance, shaping the ability to socially coexist and preparing for independent life. What is also important is the obligation contained in $\S 7$ point 1 of the Regulation of the Minister of Justice of the 14 August 2003 on the methods of penitentiary interactions in prisons and detention centres, which specifies the areas of penitentiary work aimed at preventing demoralisation, criminal subculture, self-aggression and addictions. This article postulates that the implementation of the above-mentioned legal obligations may be considered in the context of existential experiences and Machiavellianism. This postulate should be explained in two ways.

Firstly, it is noticeable that the legally required directions of social rehabilitation change are based on generally accepted and socially recognised norms as well as values relating to the axiological sphere. Concurrently, it should be emphasised that both existential concepts and the concept of the Machiavellian syndrome refer to aspects of norms and values present in the human life. The meaning of life is inextricably linked with the individual's reference to the sphere of spirituality (Frankl, 1963), overvalues (Popielski, 1987), adherence to moral standards (Steger, Kashdan, Oishi, 2008) or sources of meaning related to areas, such as positive relations with people, close emotional ties, religiosity and self-transcendence (Wong, 1998). The Machiavellian construct was introduced in psychology by Richard Christie on the basis of ideas postulated by Niccol Machiavelli. These ideas oppose the generally recognised and socially accepted vision of morality and valuation based on the promotion of effective exercise of power and control over people through manipulation and instrumental understanding of relationships with people.

Secondly, it is clear that the legally sanctioned directions of penitentiary interactions are related to building adaptation in individual and group dimensions. It should also be emphasised that in accordance with the assumptions of the creator of the logotheory Viktor Frankl (1963), the issue of experiencing and finding meaning in life is closely related to the preservation of wellbeing and mental health, and can also be understood from the perspective of coping with stressful events (Park, Folkman, 1997). The Machiavellianism syndrome finds reference to the dimension of adaptability in the individual and general social sense because it refers to the area of non-constructive attitudes and beliefs towards others as well as patterns of behaviour in social relations. Summarising the above thread, a conclusion arises that the level of existential experiences and the severity of the Machiavellian syndrome are indicators illustrating the scope of bringing convicts closer to achieving legally desired penitentiary goals. Considering the specificity of the constructs presented above, it is appropriate to determine the type of relationships between them as well as the extent to which they are correlated in a population of convicts.

\section{Existential experiences in the understanding of the presence of and search for meaning in people incarcerated numerous times}

The issue of existential experiences is inextricably linked with the question of the meaning of life. Despite the fact that these concepts refer to the well-developed and theoretical tradition in the field of health psychology and clinical psychology, dilemmas and definition doubts regarding these constructs still emerge (Debats, 1998; Krok, 2009; Trzebińska, 2008; Kriviņš et al., 2021). The concepts of "meaning" and "purpose" were introduced into the area of psychological considerations by a relatively small group of theorists. The works of V. Frankl, A. Maslow and I. Yalom (Debats, 1998) played a particularly important role here. Each of the mentioned authors was basing on various philosophical assumptions, and thus created a different theoretical vision of the problem. Many of the differences and contradictions between the concepts of these theorists relate to the heterogeneous way of capturing the values through which they defined the meaning of life. A special theoretical potential, conducive to maintaining the problem of the meaning of life in the area of the researchers' interests, should be seen in the approach postulated by V. Frankl, who while defining the meaning of life, emphasised the role of its cognitive aspects, such as attitudes, beliefs and goals (1963). In the field of Polish psychology, the elements of a cognitive approach to existential issues are being stressed in the works of K. Popielski (1994), who emphasised the relationship of meaningfulness with cognitive functioning and defined the meaning of life based on the Gestaltian metaphor of background and figure. The cognitive aspects in understanding the meaning of life were even more articulated in the work of R. Klamut (2002), who pointed to the issue of the relationship between existential issues and purposefulness. Moreover, this author stated that apart from experiencing the sense of meaning, the dimension of searching for it, 
i.e. the orientation in the mind towards gaining meaning, even in the absence of it, is also important. A particularly interesting, strictly cognitive approach to the problem of the meaning of life can be seen in the proposals of R. Baumeister (1991). At the same time, the proposals should be treated as an interesting cognitive interpretation of the assumptions of V. Frankel. Within the framework of his postulates, the author explains the relations occurring between cognitive structures concerning the meaning and sense of purpose in life. It is based on the assumption that the interpretations of life made by a person are based on putting the pieces of life together. This allows us to see a broader, integrated pattern of life, within which the elements of meaning are interrelated. According to R. Baumeister (1991), the process of integrating the elements of experience is partly based on rational reasons; however, it is also related to the temptation to obtain a global meaning, a general belief that everything in life creates meaning. The relationships and connections identified by an individual provide a basis for generalisation in the form of the creation of a general conviction, i.e. the feeling that everything in life has meaning and significance. Furthermore, striving for integration of elements of experience indicated by R. Baumeister can be understood in terms of cognitive efforts related to the search for meaning in order to obtain a sense of significance. Steger and colleagues (2006) proposed a concept that captured both aspects of meaning, i.e. its experience as well as search for it. According to these researchers, in addition to experiencing meaning in life, the dimension of reaching it as a result of activity directed at searching for it is also important. This is a development of the assumptions of V. Frankl and R. Baumeister, which concerned striving for integration of elements of experience. Thus, an individual can be characterised in terms of meaning in life in the dimension of awareness of having goals, specifically here and now goals, as well as in the dimension of striving and making effort to acquire meaning in life (Steger et al., 2006). The two dimensions, although different in nature, seem to complement each other in a temporal sense. In some way, the presence of meaning is an on-going intuition about the purposefulness and meaning of life that applies to the here and now. In contrast, the search for meaning is an activity directed towards maintaining this intuition or obtaining and strengthening it in the future. In the context of the postulates of C. Park and S. Folkman (1997), the search for meaning should be understood as an effort to use strategies based on assigning meaning.

The issue of existential experiences of repeatedly incarcerated people has not been very well understood at the empirical level. Current research using the Purpose of Life Test (PLT) scale adapted by Z. Phużek (1996) reveals that convicted recidivists have a slightly lower level of experience of meaning in life than a group of cardiac patients. However, convicted recidivists have a marginally higher level of experience of meaning in life than alcohol addicts and significantly higher than people after suicide attempts (Pietraszko, Rychlik, 2008) (See Table 1).

Table 1. Mean and standard deviation of the sense of meaning in life $(P L T)$ in the examined groups of the Polish population

\begin{tabular}{|c|l|c|c|}
\hline Item & \multicolumn{1}{|c|}{ Group } & $M$ & $S D$ \\
\hline 1. & Convicted penitentiary recidivists & 106.88 & 23.22 \\
\hline 2. & Cardiac patients (Ostrowski, 2002) measurement 1 & 118.71 & 13.08 \\
\hline 3. & Cardiac patients (Ostrowski, 2002) measurement 2 & 112.52 & 13.65 \\
\hline 4. & Control group (Cakiera, 2005) & 114 & $\mathrm{n} / \mathrm{a}$ \\
\hline 5. & Alcohol addicts (Cakiera, 2005) & 96 & $\mathrm{n} / \mathrm{a}$ \\
\hline 6. & Drug addicts (Cakiera, 2005) & 77 & $\mathrm{n} / \mathrm{a}$ \\
\hline 7. & People after suicide attempts (Cakiera, 2005) & 66 & $\mathrm{n} / \mathrm{a}$ \\
\hline
\end{tabular}

Source: Pietraszko, Rychlik, 2008

The conducted literature review did not provide information on the intensity of the search for the meaning and purpose of life by convicted recidivists. Nevertheless, the data presented above indicate that people who are repeatedly incarcerated trigger "meaning-generating" processes. It should be noted that the conditions of penitentiary isolation bring several inconveniences and restrictions related to the realisation of needs and aspirations. Solitary confinement requires reorientation as well as creation of a new understanding of one's life. The cited results suggest that at least for some detainees, this process is successful because they maintain a relatively correct level of the sense of meaning compared to other groups. It is highly likely that convicts would experience a sharp reduction in their sense of meaning if these processes did not occur. It is also plausible that the current conditions in penitentiary facilities relating to the range of rights, interventions and support available to prisoners, as well as the increase in ethical and pragmatic standards aimed at working with prisoners, constitute 
a factor supporting the functioning of prisoners in the sphere of meaning in life. Although it is not the subject of this article, it should be emphasised that the Polish penitentiary system has a wide range of resources at its disposal for conducting penitentiary activities aimed at improving the psychosocial functioning of inmates. It is worth mentioning the diagnostic centres that function at each district inspectorate of the Prison Service, numerous therapeutic wards with different specialisations, as well as the considerable range of available resocialisation and readaptation programmes. Prison conditions and the on-going efforts of the Prison Service directed at improving the psychosocial situation of prisoners are the factors, which reduce the likelihood of strong crisis experiences in this group. Nonetheless, such crises are undoubtedly difficult to completely prevent due to the fact that they are conditioned by various individual predispositions, which may be subject to interactions in relation to social and environmental factors specific to each individual prisoner.

\section{Machiavellianism in the context of the experience of penitentiary isolation by recidivists}

At present, Machiavellianism is understood as a personality trait, i.e. a syndrome related to obtaining benefits for oneself based on interpersonal manipulation (Fehr, Samsom, Paulhus, 1992; Wilson, Near, Miller, 1996). When describing Machiavellians, A. Szmajke (2001) points to their approval of a life strategy aimed at achieving domination over other people based on manipulation, the use of which is sanctioned by negative views on the human nature. At the same time, it is noticeable that Machiavellianism also contains an aspect of negative references to moral norms (Pospiszyl, 2000). Hence, it can be stated that both descriptive (detailing) and prescriptive (motivating) beliefs are present within the Machiavellian syndrome. Descriptive ones concern the negative view of the human nature. In contrast, prescriptive beliefs are associated with undertaking manipulation to achieve control and build dominance over people as well as to gain personal benefits.

Concurrently, in the context of functioning of a Machiavellian in isolation, it should be noted that in these conditions, especially in closed type units, which significantly limit the freedom to control the interactions with other convicts, Machiavellians are particularly vulnerable to experiencing frustration in relation to the pursuit of their aspirations. It is also important to note that this frustration can be compounded by the risk of being identified by the environment as being manipulative, and the environment of closed type units does not allow for an easy change of environment. Thus, there may be an extreme limit to the fulfilment of Machiavellian aspirations. The second category of Machiavellian beliefs, i.e. the descriptive ones, does not serve to adapt to the conditions of isolation. This is because they condition the understanding of others in terms that are unsupportive of coping based on the use of social resources, in particular emotional support. Hence, the situation of isolation is for Machiavellians particularly aggravating because they become victims of their aspirations and beliefs, which form fetters preventing them from functioning effectively in a closed environment. On the one hand, these fetters make them experience the frustration of striving, while on the other hand, Machiavellians find it difficult to share their own suffering on the basis of establishing an honest interpersonal relationship, in which they would receive emotional support. Thus, it must be presumed that in conditions of isolation, Machiavellianism should reveal a very clear negative relationship with the general level of adaptation.

\section{Relationships between Machiavellianism and the presence of and search for meaning in life in recidivists}

A review of the literature on the subject indicates that there is a shortage of studies providing direct knowledge on the potential relationships between Machiavellianism and the dimension of existential experiences of penitentiary recidivists. Some knowledge is provided by studies utilising a tool called the Purpose in Life Test (PIL). Such works were not based on the classical approach to Machiavellianism, but referred to the conceptualisation proposed by S. Corral and C. Calvete (2000). As part of this approach, the authors distinguished positive and negative interpersonal tactics as well as positive and negative views on the human nature. In these studies, the sense of the meaning of life revealed positive correlations only with positive interpersonal strategies $(r=0.47)$ (Pietraszko, Rychlik, 2008). When raising the issue of the need for a more detailed verification of the relationship between these constructs, it should be emphasised that this necessity primarily results from the theoretical aspects concerning the axiological dimension of both concepts presented above as well as from studies revealing their relationships with various indicators of adaptation and wellbeing. 


\section{Relationships between the sense of meaning and adaptation}

As previously indicated, the sense of meaning in life is a concept that is firmly established in the area of health psychology and clinical psychology. This is evident in the theoretical sources of this concept, which are derived from the postulates of V. Frankl (1963) and A. Antoniovsky. It is worth pointing to the main studies that confirm the characteristics of this relationship. It was concluded, inter alia, that the sense of meaning in life positively correlated with self-awareness (Steger, Kashdan, Oishi, 2008) and inner sense of control (Newcomb, Harlow, 1986) as well as with self-esteem (Reker, 1977). Moreover, it has been shown that experiencing meaning in life exhibits positive correlations with life satisfaction (Steger, Kashadan, 2007), subjective quality of life in the form of global happiness (Reker, Peacock, Wong, 1987; Debats, 1996). Similar results were obtained in several other studies (Chamberlain, Zika 1992; Sagy, Antonovsky, Adlera, 1990). It should be mentioned that there is also a wide range of results illustrating moderate, negative correlations between the sense of meaning in life and depression indicators (Battista, Almond, 1973; Dyck, 1987; Reker, Peackok, Wong, 1987; Flannery, Flannery, 1990; Debats, 1996). Negative correlations were also found between the level of experiencing the sense of meaning in life and the intensification of the sense of hopelessness (Grygielski, Januszewska, Januszewski, Juros, Oleś, 1984) as well as the intensity of suicidal thoughts (Harlow, Newcomb, Bentler, 1986) and nonsuicidal self-aggressive acts (Marco et al. 2015).

\section{Relationships between Machiavellianism and variables in the spheres of social adaptation and motivation}

As previously indicated, Machiavellianism is built on the basis of beliefs about low adaptive value caused by non-constructive understanding of relationships with people (i.e., on the basis of negative descriptive beliefs). It is also built in reference to non-constructive motivational beliefs (i.e., prescriptive ones), which are focused on exploiting the surroundings and potential social interaction partners. When it comes to the first aspect of conviction, it has been demonstrated that Machiavellianism negatively correlates with the valuation of participation in community, having friends and family (McHoskey, 1999). In contrast, it positively correlates with shyness (Gurtman, 1992), perceived jealousy, the feeling of being its object (Vecchio, 2005) as well as hostility (Marušić, Bratko, Zarevski, 1995). Moreover, it has been shown that there are negative correlations between Machiavellianism and trust (Gurtman, 1992) as well as empathy (Austin, Farrelly, Black, Moore, 2007). Considering the aspect of motivational beliefs of Machiavellians, it has been revealed that their actions are grounded by external goals - most often material ones (McHoskey, 1999; Pilch, 2008a). In addition, it was found that Machiavellians are characterised by a low level of moral reasoning (Latif, 2000) as well as a tendency to display unethical behaviour (Granitz, 2003; after: Pilch, 2008b; Jones and Paulhus, 2009; Wirtz and Kum, 2004). It has been determined that Machiavellians lie more often than non-Machiavellians. They enjoy it and it comes more easily to them (Gozna, Vrij and Bull, 2001; Kashy and DePaulo, 1996; after: Pilch, 2008a).

\section{Conclusions from previous studies on Machiavellianism and the sense of meaning in life for research on the functioning of recidivists}

Studies conducted so far show that the sense of meaning in life and Machiavellianism are related to a similar spectrum of variables concerning health, which is perceived from an individual perspective as well as in the context of social functioning. Hence, it is possible that both constructs reveal direct interrelationships with each other. These relationships should be particularly evident in conditions of isolation, when Machiavellians are exposed to frustrations regarding their aspirations, goals and contact with the environment, in which their belief system does not fulfil an adequate regulatory function due to the limited possibilities of carrying out more extensive manipulative activities. Considering the above, one should also take into account the research results indicating that Machiavellians show a high level of cognitive rigidity (Primavera and Higgins, 1976; after: Pilch, 2008b); therefore, they have limited possibilities of modifying the perception of the situation of imprisonment and flexibility in the scope of appropriate proceeding strategies. Consequently, they are more exposed than others to experiencing failures in terms of adaptation, which should also be manifested in the area of searching for meaning as well as experiencing it. 


\section{Research procedure}

The research goal was to establish quantitative relationships between the considered variables. ${ }^{1}$ The study was based on self-reporting utilising appropriate questionnaire tools. The questionnaires were filled using a paperpencil method. Participation in the research was anonymous and voluntary. The research procedure included 59 penitentiary recidivists who were serving a sentence of imprisonment in the Penitentiary Facility in Racibórz in 2020. Inmates aged 27 to 68 were examined $(M=39.75, S D=8.84)$.

\section{Research methods}

Two questionnaires were used in the study: Mach IV (R. Christie and F. Geis) in the adaptation of K. Pospiszyl (2000), the scale of the Meaning in Life Questionarie (MLQ) (Steger, Frazier, Oishi, Kaler, 2006) in the Polish adaptation of M. Kossakowska, M., P. Kwiatek, P., T. Stefaniak (2013).

The Mach $I V^{2}$ scale developed by R. Christie and F. Geis (1970; after Pospiszyl, 2000) is used to describe the Machiavellian personality. It consists of twenty statements, which are rated on a seven-point scale (1 - "I completely disagree", 7 - "I completely agree"). The individual scores are summed up, and subsequently twenty points are added to obtain the Machiavellianism level index. The higher the score, the higher the Machiavellianism level (Pospiszyl, 2000; Pilch, 2008a). The overall score includes subscales, such as "Tactics", "Views on the human nature" and "Morality". The "Tactics" scale concerns the use of environmental manipulation tactics. The scale of "Views on the human nature" is related to the level of intensity of negative perception of other people. The "Morality" scale refers to the degree of disregard for norms. The Meaning in Life Questionnaire $(M L Q)^{3}$ (Kossakowska, Kwiatek, Stefaniak, 2013) is used to measure the presence of sense and search for meaning in life. The dimension of the presence of meaning concerns the actual experience of the purpose and meaning in life. The search aspect is related to the pursuit and effort to increase the sense of meaning, its maintenance or restoration in the future.

\section{Conclusions}

As part of the descriptive data analysis, the mean values and standard deviations of the studied variables were determined in order to conduct a preliminary assessment of their distributions. Table 2 presents the means and standard deviations of individual indicators of Machiavellianism as well as the presence of and search for meaning in life.

Table 2. Means and standard deviations for indicators relating to Machiavellianism, sense of and search for meaning in life

\begin{tabular}{|c|c|c|c|}
\hline Item & Indicators of Machiavellianism (Mach IV) & $M$ & $S D$ \\
\hline 1. & Machiavellianism - global index & 94.94 & 15.89 \\
\hline 2. & Machiavellianism - "Tactics" and "Views on the human nature" & 86.88 & 14.36 \\
\hline 3. & Machiavellianism - "Tactics" & 46.32 & 8.17 \\
\hline 4. & Machiavellianism - "Views on the human nature" & 60.55 & 8.67 \\
\hline 5. & Machiavellianism - "Morality" & 28 & 2.67 \\
\hline
\end{tabular}

\begin{tabular}{|c|l|c|c|}
\hline Item & Indicators of the presence of and search for meaning in life measured by the $M L Q$ questionnaire & $M$ & $S D$ \\
\hline 1. & Presence of meaning in life & 27.13 & 6.96 \\
\hline 2. & Search for meaning in life & 25.15 & 7.38 \\
\hline
\end{tabular}

1 In this study, the Statistica 13.3 program was used to perform all calculations.

2 Cronbach's reliability coefficients for Mach IV, determined on the basis of the data collected during the study, were: alpha $=0.73$ (for the overall score Mach IV), alpha $=0.57$ (for the "Tactics" scale), alpha $=0.59$ (for the "Views on the human nature" scale). The Cronbach's coefficient for the "Morality" scale proved to be insufficient as it obtained a value of alpha $=0.22$.

3 The Cronbach's alpha reliability coefficient for the presence of meaning in life was alpha $=0.86$, while for the search for meaning in life, the value was alpha $=0.89$. Very similar indicators were obtained in adaptation studies: alpha $=0.86$ for the presence of meaning in life and alpha $=0.72$ for the search for meaning in life). 
Normality tests were performed to identify the specificity of the analysed variables in detail. It was revealed that with the exception of the global index of Machiavellianism, all variables relating to Machiavellianism obtained a distribution relatively consistent with the Gaussian curve. In contrast, the meaning in life variables did not meet the normality condition.

The obtained distributions indicated that the analysis of the strength of the correlations should be based on a rank factor. Thus, the calculation was based on the Spearman's rank-order correlation coefficient R. Table 3 shows the correlations of the two dimensions of meaning in life with four distinguished indicators of Machiavellianism.

Table 3. Correlations between the dimensions of eudaimonistic wellbeing and four indicators of Machiavellianism

\begin{tabular}{|l|c|c|c|c|c|}
\hline \multicolumn{1}{|c|}{ Indicators } & $\begin{array}{c}\text { Global Index - "Tactics", } \\
\text { "Views" and "Morality" }\end{array}$ & "Tactics" and "Views" & "Tactics" & "Views" & "Morality" \\
\hline Presence of meaning in life & $-0.48^{*}$ & $-0.42^{*}$ & $-0.56^{*}$ & -0.14 & $-0.36^{*}$ \\
\hline Search for meaning in life & $-0.34^{*}$ & $-0.30^{*}$ & $-0.48^{*}$ & 0.03 & -0.23 \\
\hline
\end{tabular}

*Spearman's rank-order correlation coefficients R significant at $\mathrm{p}<0.05$.

When analysing the results presented in Table 3, it can be seen that the presence of meaning in life shows a negative correlation with Machiavellianism in terms of the global scale, capturing both "Tactics" and "Views on the Human Nature", as well as with "Tactics" and "Morality" alone. The search for meaning in life exhibits negative correlations with global Machiavellianism and the dimension including "Tactics" and "Views" as well as with the "Tactics" dimension on its own. The correlations between the "Presence of meaning in life" and "Views on the human nature", as well as those between the "Search for meaning in life" and "Views on the human nature" and "Morality", were found to be insignificant ${ }^{4}$.

Considering the obtained results, two types of conclusions that are relevant to the problem of resocialisation can be drawn. Firstly, it is important that the implementation of resocialisation programmes, which modify Machiavellian beliefs, particularly those relating to the motivational dimension, i.e. the prescriptive ones justifying manipulation for egocentric gains, can foster the solution of significant penitentiary problems related to the instability of psychosocial functioning of inmates during their sentence (e.g., by reducing their suicidal risks and self-aggressive tendencies). It is important to emphasise that the lack of the sense of meaning in life is linked to suicidal tendencies (Newcomb, Lorence, Scheier, Bentler, 1993) and non-suicidal auto-aggression (Marco et al.,

2015). Furthermore, the correlations between morality and the presence of meaning provide a rationale suggesting that challenging Machiavellian beliefs and interactions directed towards the development of the axiological sphere should foster the construction of meaning in life, thus enhancing the level of overall adaptation.

The second conclusion that emerges concerns the mechanism of introducing constructive changes in the functioning of inmates. The results suggest that Machiavellians, particularly those convinced of the validity of the use of manipulation, do not seek the meaning in life. Hence, it must be presumed that stabilising their functioning should require processes that disintegrate previous motivational structures referring to egocentrism. This seems likely given the close relationship between Machiavellianism and narcissism (Pilch, 2008a). The negative correlation between Machiavellianism and searching for meaning can also be referred to the concept of coping through giving meaning, which was previously reported by C. Park and S. Folkman (1997). Machiavellians are individuals who do not search for meaning; thus, they may have particularly great difficulties adapting to situations involving lack of control without personal instrumental influence. Hence, it seems that conditions of

4 The results relating to "Morality" should be interpreted with great caution due to the fact that this subscale did not achieve a sufficient level of reliability. The results presented in this area are only intended to present the potential specificity of the correlation between the "Morality" of Machiavellians and the dimensions of their quality of life. It is also important that the obtained value of correlation suggests the presence of a trend, which indicates the possibility of a significant correlation in the case of increasing the reliability of the Morality scale. 
isolation are particularly threatening for them as they might result in disintegration. The conclusion is that this category of convicts requires the introduction of compensatory measures, which could make this disintegration constructive, e.g. in the sense of the assumptions postulated by K. Dąbrowski. When experiencing stress relating to isolation, these inmates might require particularly intensive stimulation for cognitive reorientation.

Analysis of the obtained data also reveals the issue of the difficulty of interpreting results that are inconsistent with the expected outcomes. These concern the lack of correlations between the negative views on the human nature and both the presence of and search for meaning. To explain this result, it is useful to distinguish the descriptive and prescriptive aspects of Machiavellianism. It is noteworthy that having negative beliefs about other people is not the same as having strategies aimed at harming others for one's own purposes. According to the logotheoretical postulates of V. Frank1, this is directly connected to the violation of standards, which are considered as foundations of experiencing and creating meaning in life. This problem can also be explained by the previously discussed topic of egocentricity. Notably, just having negative beliefs about others is not necessarily related to egocentrism. Nevertheless, it cannot be ruled out that the core, on which strategies aimed at other people are built, may be egocentrism. This opposes the transcendental vision of the emergence of meaning in life in logotheoretical terms.

\section{Discussion}

The article indicates the relevance of the issues of Machiavellianism and meaning in life for rehabilitation and penitentiary issues. In the context of these assumptions, it was determined that the constructive undermining of Machiavellian schemes and beliefs through implementation of interventions directed at the search for meaning in life as well as its maintenance might be a resocialising factor, stabilising the foundation of convicts during their sentence. Considering the obtained results, it is necessary to indicate the possibility of conducting rehabilitation based on a change referring to positive disintegration, i.e. the creation of new structures enabling understanding of the world and determining the direction of the individuals' actions on the basis of the disintegration of previous ones that might take place in conditions of experiencing a crisis related to the inadequacy of previous cognitive structures relating to Machiavellian vision of the world and people. This process can also be understood in terms of triggering the assimilation of new regulatory standards allowing for more effective creation of meaning or construction of new sources of meaning to replace those relating to egocentric orientation.

To some extent, the obtained results were not consistent with the expected outcomes. It should be noted that in terms of prescriptive beliefs (i.e., those concerning negative views of the human nature), Machiavellianism did not show negative correlations with either the search for meaning in life or its presence. This issue requires further research in the context of finding mediators or moderators. It is plausible that other personality aspects might determine the occurrence of this highly probable correlation. Given the fact that this relationship occurs in relation to Machiavellian tactics aimed at gaining self-interest, further research should consider the control of variables from the area of narcissism and egocentric orientation.

\section{References}

Antonovsky, A. (1995). Rozwiktanie tajemnicy zdrowia: Jak radzić sobie ze stresem i nie zachorować [Unravelling the mystery of health: How people manage stress and stay well]. Warsaw: Foundation of the Institute of Psychiatry and Neurology.

Austin, E.J., Farrelly, D., Black, C. and Moore, H. (2007). Emotional intelligence, machiavellianism and emotional manipulation: Does EI have a dark side? Personality and Individual Differences, 43, 179-189.

Battista, J., Almond, R. (1973). The development of meaning in life. Psychiatry, 36 (4), 409-427.

Baumeister, R.F. (1991). Meanings in life. New York: The Guilford Press.

Chamberlain, K., Zicka, S. (1992). Religiosity, meaning in life, and psychological wellbeing. In: JF Schaumaker (ed.), Religion and mental health (pp. 138-148). NewYork, NY: Oxford University Press.

Coral, S. Calvete, E. (2000). Machiavellianism: Dimensionality of the Mach IV and its Relation to Self-Monitoring in Spanish Sample. 
The Spanish Journal of Psychology, 3, 1, 3-13.

Dąbrowski, K. (1979). Dezintegracja pozytywna [Positive Disintegration]. Warsaw: PIW.

Debats, D. L. (1998). The measurement of personal meaning. In: Wong, P. T. P., Fry, P. S. (ed.), Handbook of Personal Meaning: Theory, Research, and Application (pp. 111-140). Mahwah, NJ: Lawrence Erlbaum.

Fehr, B., Samsom, D. and Paulhus, D. L. (1992). The construct of Machiavellianism: Twenty years later. In: Spielberger, C.D. and Butcher, J. N. (ed.), Advances in Personality Assessment (vol. 7, pp. 77-116). Hillsdale, NJ: Erlbaum.

Flannery, R. B., Flannery, G. J. (1990). Sense of coherence, life stress, and psychological distress: A prospective methodological inquiry. Journal of Clinical Psychology, 46, 415-420.

Frankl, V. E. (1963). Man's search for meaning: An introduction to logotherapy. New York: Washington Square Press.

Grygielski, M., Januszewska, E., Januszewski, A., Juros, A., Oleś, P. (1984). Meaning in life and hopelessness: Interrelationships and intergroup differences. Polish Psychological Bulletin, 15 (4), 277-284.

Gurtman, M. B. (1992). Trust, distrust, and interpersonal problems: A circumplex analysis. Journal of Personality and Social Psychology, 62, 989-1002.

Klamut, R. (2002). Cel - czas - sens życia [Purpose - time - meaning of life]. Lublin: Towarzystwo Naukowe Katolickiego Uniwersytetu Lubelskiego [The Learned Society of the Catholic University of Lublin].

Kossakowska, M., Kwiatek, P., Stefaniak, T. (2013). Sens w życiu [The meaning in life]. Polish version of the Meaning in Life Questionnaire $(M L Q)$. Obtained from: [www.researchgate.net/publication/261705545_Sens_w_zyciu_Polska_wersja_kwestionariusza_MLQ Meaning_in_Life_Questionnaire_Meaning_in_Life_Polish_Version_of_MLQ/link/ $\overline{0} 04 \overline{6} 353514426 \mathrm{~d} 3 \mathrm{~b} \mathrm{~b} 4000000 \mathrm{~d}$ dated11/17/2020

Krok, D. (2009). Religijność a jakość życia w perspektywie mediatorów psychospolecznych [Religiousness and the quality of life in the perspective of psychosocial mediators]. Opole: Wydawnictwo WT UO [WT UO Publishing house].

Kriviņš, A., Teivāns-Treinovskis, J., Tumalavičius, V. (2021). Issues of state and national security: Religiously inspired terrorism in the Baltic States: internal and external factors. Insights Into Regional Development, 3(1), 65-79. http://doi.org/10.9770/IRD.2021.3.1(4)

Latif, D. A. (2000). The relationship between pharmacy students' locus of control, Machiavellianism, and moral reasoning. American Journal of Pharmaceutical Education, 64, 33-37.

Marco, J. H., Garcia-Alandete, J., Perez, S., Guillen, V., Jorquera, M., Espallargas, P., Botella, C. (2015). Meaning in life and nonsuicidal self-injury: A follow-up study with participants with Borderline Personality Disorder. Psychiatry Research, 15(2), 561-566.

Marušić, I., Bratko, D. and Zarevski, P. (1995). Self-reliance and some personality traits: sex differences. Personality and Individual Differences, 19(6), 941-943.

McHoskey, J. W. (1999). Machiavellianism, intrinsic versus extrinsic goals, and social interest: A self-determination theory analysis. Motivation and Emotion, 23(4), 267-283.

Newcomb, M. D., Harlow, L. L. (1986). Life events and substance use among adolescents: mediating effects of perceived loss of control and meaninglessness in life. Journal of Personality and Social Psychology, 51 (3), 564-577.

Park, C. L., Folkman, S. (1997). Meaning in the context of stress and coping. Review of General Psychology, 1 (2), $115-144$.

Pietraszko, J., Rychlik, J. (2008). The feeling of Meaning in Life in men confined in prison and the degree of their approval towards Machiavelli's views (exploratory study). In: Głębocka, A., Gawor, A. (ed.), Quality of Life - Different Perspectives (pp. 63-84). Krakow: Impuls.

Pilch, I. (2008a). Emocje i osobowość makiawelisty [Emotions and personality of a Machiavellian]. In: Błachnio, A. and Przepiórka, A. (ed.), Bliżej emocji II [Closer to emotions II] (pp. 99-110). Lublin: Wydawnictwo KUL [KUL Publishing house].

Pilch, I. (2008b). Osobowość makiawelisty i jego relacje z ludźmi [Personality of a Machiavellian and their relations with people]. Katowice: Wydawnictwo Uniwersytetu Śląskiego [University of Silesia Press].

Płużek, Z. (1996). Osobowościowe uwarunkowania pytania o sens życia [Personality determinants of the question about the meaning in life]. In: Popielski, K. (ed.), Człowiek - wartości - sens. Studia z psychologii egzystencji [Human - values - meaning. Studies in psychology of existence] (pp. 365-370). Lublin: Wydawnictwo Katolickiego Uniwersytetu Lubelskiego [Publishing house of the Catholic University of Lublin]. 
Popielski, K. (1987). „Sens” i „wartość” życia jako kategorie antropologiczno - psychologiczne [The "meaning” and “value” of life as anthropological and psychological categories]. In: Popielski, K. (ed.), Człowiek-pytanie otwarte. Studia z logoteorii i logoterapii [Human - an open question. Studies in logotheory and logotherapy] (pp. 107-140). Lublin: Wydawnictwo Katolickiego Uniwersytetu Lubelskiego [Publishing house of the Catholic University of Lublin].

Pospiszyl, K. (2000). Psychopatia [Psychopathy]. Warsaw: Wydawnictwo Akademickie Żak [Żak Academic publishing house]

Reker, G. T. (1977). The Purpose in Life test in an inmate population: An empirical investigation. Journal of Clinical Psychology, 33, 668-693.

Reker, G. T., Peacock, E. J., Wong, P. T. P. (1987) Meaning and purpose in life and wellbeing: A life span perspective. The Journal of Gerontology, 42, 44-49.

Sagy, S., Antonovsky, A., Adler, I. (1990). Explaining life satisfaction in later life: The sense of coherence model and activity theory. Behavior, Health, \& Aging, 1 (1), 11-25.

Steger, M. F., Frazier, P., Oishi, S., Kaler, M. (2006). The meaning in life questionnaire: Assessing the presence of and search for meaning in life. Journal of Counseling Psychology, 53, 1, 80-93.

Steger, M. F., Kashdan, T. B., (2006). Stability and specificity of meaning in life and life satisfaction over one year: Implications for outcome assessment. Journal of Trauma and Happiness Studies, 8, 161-179.

Steger, M. F., Kashdan, T. B., Oishi, S. (2008). Being good by doing good: Daily eudaimonic activity and well-being, Journal of Research in Personality, 42 (1), 22-42.

Szmajke, A. (2001). Jacyż są makiaweliści [What are Machiavellians like]. In: Doliński, D. and Weigl, B. (ed.), Od myśli i uczuć do decyzji $i$ działań [From thoughts and feelings to decisions and actions] (151-166). Warsaw: Instytut Psychologii PAN [Institute of Psychology of the Polish Academy of Sciences].

Trzebińska, E. (2008). Psychologia pozytywna [Positive psychology]. Warsaw: Wydawnictwo Akademickie i Profesjonalne [Academic and Professional Publishing House].

Vecchio, R. P. (2005). Explorations in employee envy: Feeling envious and feeling envied. Cognition and Emotion, 19(1), 69-81.

Wilson, D. S., Near, D. and Miller, R. R. (1996). Machiavellianism: A synthesis of the evolutionary and psychological literatures. Psychological Bulletin, 119(2), 285-299.

Wong, P. T. P. (1998). Implicit theories of meaningful life and the development of the Personal Meaning Profile (PMP). In: Wong, P. T. P., Fry, P. (ed.), Handbook of personal meaning: Theory, research, and practice (pp. 111-140). Mahwah, NJ: Lawrence Erlbaum.

Act of 6 June 1997, Kodeks karny wykonawczy [Executive Penal Code], (Journal of Laws of 2020, item523).

Rozporządzenie Ministra Sprawiedliwości [Regulation of the Minister of Justice] of 14 August 2003, (Journal of Laws of 2003, No. 151, item 1469).

Jarosław RYCHLIK is a doctor of social sciences in the field of psychology. He completed MA studies at the Institute of Psychology at the University of Opole, and then doctoral studies at the Faculty of Pedagogy and Psychology at the University of Silesia. He started working in the Prison Service in 2006 in the Penitentiary Institution in Racibórz. He was associated with this unit for over 14 years. There, he was entrusted with the role of a psychologist in the penitentiary department, and then the therapeutic department for convicts with non-psychotic mental disorders or mentally handicapped. From 2016, he served as the head of this department. Since 2020, he has been serving at the Academy of Justice as an adjunct professor. His research interests include constructive thinking, structural and functional aspects of the meaning of life, coping with stress and penitentiary psychology. He is the co-author of several publications concerning, inter alia, the issue of the functioning of inmates in conditions of prison isolation. He participated in many scientific conferences presenting the results of the conducted research, and was also appointed to the role of a member of discussion panels.

ORCID ID: https://orcid.org/0000-0002-1948-1882

This work is licensed under the Creative Commons Attribution International License (CC BY). http://creativecommons.org/licenses/by/4.0/ 